\title{
Undernutrition Among Under-Five Children in Two Fishing Communities in Mafia Island Marine Park, Tanzania
}

\author{
Victoria Hippolite Moshy ${ }^{1,2}$, Theopista Jacob Masenge ${ }^{3} \&$ Ian Bryceson $^{1}$ \\ ${ }^{1}$ Department of International Environment and Development Studies (Noragric), University of Life Sciences, \\ Norway \\ ${ }^{2}$ Institute of Resource Assessment, University of Dar es Salaam, Dar es Salaam, Tanzania \\ ${ }^{3}$ Department of Paediatrics and Child Health, Muhimbili National Hospital, Dar es Salaam, Tanzania \\ Correspondence: Victoria H. Moshy, Department of International Environment and Development Studies \\ (Noragric), University of Life Sciences, P. O. Box 5003, NO-1432 Ås, Norway. Tel: 47-4056-7197/ \\ 255-784-590-921. E-mail: victoria.moshy@umb.no/moshyv2001@yahoo.com
}

Received: November 12, $2012 \quad$ Accepted: April 17, $2013 \quad$ Online Published: May 3, 2013
$\begin{array}{ll}\text { doi:10.5539/jsd.v6n6p1 } & \text { URL: http://dx.doi.org/10.5539/jsd.v6n6p1 }\end{array}$

\begin{abstract}
Undernutrition and food insecurity are critical problems among under-five children in many developing countries. This study was carried out for eight months between 2009 and 2011. It combined quantitative data $(\mathrm{N}=156)$ and qualitative data to explore nutritional status among under-five children in Jibondo and Chole villages within Mafia Island Marine Park in Tanzania. Weight-for-age analysis was performed according to World Health Organization standards to determine the proportion of underweight children among the samples. The prevalence of underweight children was high in both villages, and in Jibondo village it was even higher (69\%) than in Chole village (40\%). Interviewees attributed the exceptionally high underweight problems in Jibondo to a substantial reduction in breast-feeding frequency. This was because mothers resumed seaweed farming and octopus fishing soon after delivery. Consequently, infants were fed poor-quality nutritional substitute foods at a tender age. Decreased family income, food insecurity, changes in gender roles and increased responsibilities for women were also perceived to be key underlying problems contributing to higher levels of undernutrition among children in the study areas. If healthy generations and sustainable social-ecological systems are to be achieved within the Park in the future, policies that review fishing restrictions, improve fish trading, increase household food security and liberate mother's time for breastfeeding and child-caring activities would be essential to address the current undernutrition among the under-fives.
\end{abstract}

Keywords: undernutrition, food insecurity, under-five children, Mafia Island Marine Park, Tanzania

\section{Introduction}

Undernutrition persists as a major threat to both physical development and health of millions of children below five years of age in the developing countries (Pelletier, Frongillo, Schroeder \& Habicht, 1995; World Health Organization (WHO), 2005; United Nations Children's Fund [UNICEF], 2012). It is a critical problem that contributes nearly one third of total deaths among under-five children in the world (UNICEF, 2009). Prevalence of undernutrition is high in most African countries, Somalia being the most affected (UNICEF, 2009, 2012). Undernutrition is thus among the challenges that constrain global efforts to reduce child mortality by two thirds by the year 2015 as part of the United Nations Millennium Development Goals (MDGs) launched in 2000 (www.un.org/millenniumgoals/). Most developing countries are still far from achieving this goal (de Onis, Blössner, Borghi, Frongilo, \& Morris, 2004) as the numbers are projected to remain high even until the year 2020 (Smith \& Haddad, 2000). In 2009, Tanzania was reported to be making insufficient progress towards the 2015 target (UNICEF, 2009).

Undernutrition as a form of malnutrition is mostly observed among under-five children in developing countries through failure of physical growth, although micronutrients deficiency diseases are also high among children (Muller \& Krawinkel, 2005). According to UNICEF (2009), failure to grow is easily observed through three forms of malnutrition. First, acute malnutrition or wasting, in which cases, children remain thin with low weight for their height. Second, chronic malnutrition or stunting, results in children remaining too short for their age. 
Third, either or both acute and chronic malnutrition cause a condition of underweight, whereby children have low weight for their age and might be stunted and/or wasted. Assessment of underweight through weight-for-age analysis is a widely practiced method in evaluating growth patterns and body proportions because it reflects both acute and chronic malnutrition (de Onis, Monteiro, Akre \& Glugston, 1993; Shetty, 2003; Nube \& Sonneveld, 2005; UNICEF, 2009; Zavoshy, Noroozi, Jahanihashemi, \& Kiamiri, 2012).

The factors that contribute to undernutrition among the children under the age of five in developing countries are complex. Immediate causes include diseases, improper breast-feeding practices, and poor or inadequate intake of diet and substitute foods in terms of quality, quantities and frequency (Mahgoub, Nnyepi \& Bandeke, 2006; Black et al., 2008; Leach \& Kilama, 2009; UNICEF, 2009, 2012; Sunguya et al., 2011). The underlying causes include poverty and shortage of capital including income, and maternal education; household food insecurity; changes in gender relations and roles including increased work load for women; inadequate child care; unfavourable household environmental conditions; inadequate social services; environmental changes and conservation practices; spatial and social inequalities; and the global trends of trade liberalization, financial crises and increases in food prices (Kent, 1997; Black et al., 2008; Mahgoub et al., 2006; Gabriele \& Schettino, 2008; UNICEF, 2009; WHO, 2010).

Women and children, particularly the under-fives, are among the most vulnerable groups in areas that experience food insecurity, inadequate diets and undernutrition (Blössner \& de Onis, 2005, Nyaruhucha, Msuya, Mamiro, \& Kerengi, 2006; United Republic of Tanzania [URT] 2011; UNICEF 2012). Inadequate diet affects under-five children more than other age groups because under-fives grow rapidly, and need more nutrient-rich diet for their growth and development (Blossner \& de Onis, 2005). Individuals exposed to childhood undernutrition have been reported to face permanent socioeconomic and health consequences that have a potential to contribute to adverse impacts on their environment in the future. These consequences include: prevalence of metabolic and cardiovascular diseases; reduced learning ability, lowered years of schooling and intellectual performance in adulthood; reduced working ability, productivity and income; poor quality of life and overall poverty that is mostly transferred to the future generations. These conditions have the potential to contribute towards environmental degradation and unsustainable resource use (McGregor et al., 2007; Black et al., 2008; Walton \& Allen, 2011; UNICEF, 2012; Zavoshy et al., 2012).

Moreover, children under the age of five continue to receive little attention in social-ecological studies. Most such studies focus on the resilience, vulnerability and sustainability of coupled social-ecological systems, with emphasis on the current resource users, their traditional ecological knowledge, institutions governing their interactions with environment and their response to changes (Berkes \& Folke, 1998). The traditional ecological knowledge of a particular environment is increasingly incorporated in the current efforts to understand and manage the ever-changing social-ecological system for resilience and sustainability (Berkes \& Folke, 1998; Young et al., 2006). However, traditional ecological knowledge is mainly possessed by resource users who have learnt the knowledge by practicing and have accumulated it through experience over long periods of time, from childhood to adulthood. The ability to learn, practice and accumulate this knowledge requires healthy minds and bodies from the early stages of life.

Most of the causal factors of undernutrition mentioned above and little attention to the under-five children in social-ecological studies are evident in Mafia Island. Poor dietary intake, inability to access fish for household consumption and mothers' worries about the quality of diets for their children are documented in Walley (2004) and Ash, Takala and Latham (2007). Marine environmental changes including damaged corals from past coral bleaching event and dynamite fishing, and reduced depth of sea water have been reported to influence distribution of fish species, amount of catch per individual fisher and household fish consumption (Ohman, Lindahl, \& Schelten, 1999; Garpe \& Ohman, 2003; Moshy, Bryceson, \& Beymer-Farris, 2012). Meanwhile, the establishment of the first marine park in Tanzania and the largest in Africa, Mafia Island Marine Park (MIMP) and its operations have constrained resource dependent communities from accessing rich fishing grounds (Andrews, 1998; Mwaipopo, 2008; Benjaminsen \& Bryceson, 2012). These have in turn contributed to decreased income, increased food insecurity and change on gender roles where women are increasingly engaged in economic activities to complement men's decreasing income (Walley, 2004; Bryceson et al., 2006; Benjaminsen \& Bryceson, 2012).

Trade liberalization in Mafia Island manifests itself through the presence of first and largest foreign-owned marine fish processing factory in Tanzania (Caplan, 2007). The factory has contributed to decreased income to fishers by giving low prices for their fish and octopus catches such that they fail to meet their household needs, including food (Bryceson et al., 2006). It has further increased food insecurity among fishing communities through continuous collection of octopus (from men octopus divers and women octopus collectors), which were 
previously caught by women as their source of household income and food security (Bryceson et al., 2006). Walley (2004) also reports the influence of price increase in other food products on food security whereby fishers sell much of their fish catch in order to buy grains because families can survive without fish protein but not without maize and rice.

Increased investments in tourism in Mafia, particularly in Chole, have contributed to improved social services. Tourism investors in Chole facilitated villagers and built Chole Health Centre to improve maternal health. Chole Kindergarten was also built to provide education, nutritious food and day care to children under the age of five while their mother attended to their economic activities (Walley, 2004). However, the investors have constrained Chole villagers from actively engaging in tourism related activities to obtain income to complement the decreasing income from fishing due to MIMP restrictions (Benjaminsen \& Bryceson, 2012).

Although the presence of factors that contribute to undernutrition are vivid in Mafia, there is no study that has yet focussed on the assessment of physical growth among the under-five children. Albonico et al. (2002) remains the only study that has focused on children in Mafia Island, but solely on soil-based infections and treatment among school children. Walley (2004) and Ash et al. (2007) reported increased hardships among the people of Chole in obtaining fish for household consumption and affording nutritional meals, but there is still lack of information that shows the nutritional status of under-five children in Chole and other villages.

To contribute to the challenging efforts to attain resilient and sustainable social-ecological systems, it is argued that studies need to address sustainability in a more diversified manner such that attention is given to both current and future resource users. We consider it equally important to focus on the under-fives, who are also considered in this paper as 'future resource users' currently residing in Mafia Island. The understanding of nutritional status and growth of these future resource users is crucial for maintaining transfer of traditional ecological knowledge across generations. The under-five children also deserve attention because they are the future resource managers, and as such it is crucial to ensure their development in their early stages of life towards better capacities in the future.

Given the above premises, this study investigates the nutritional status of children under the age of five in Jibondo and Chole villages in order to contribute to the understanding of their health and growth status. The study specifically focuses on the assessment of growth among children to determine prevalence of underweight among the studied children and establish descriptions of their nutrition situation and the local perceptions of possible explanations for the underweight prevalence. The study employs weight-for-age as an appropriate measure for underweight as it combines the two aspects of body growth, linear and proportions (Shetty, 2003).

\section{Methods}

\subsection{Study Area}

This study was conducted in Mafia Island, a large archipelago that covers $407 \mathrm{~km}^{2}$ and is about $120 \mathrm{~km}$ from south-east of Dar es Salaam (Figure 1). Mafia is among the seven districts forming the Coast Region and has a population of 46438 people (URT, 2013). Mafia has rich marine biodiversity which contributed to the establishment of the first marine park in the country and the largest in Africa, the MIMP (Benjaminsen \& Bryceson, 2012). The rich marine environment supports fishing activities for both men and women, although women mainly engage on octopus fishing and seaweed farming (Bryceson et al., 2006; URT, 2007). Short rains starting from October to December and long rains that begin in March and end in May supports some agricultural activities in most areas. The people of Mafia Island also engage in other economic activities including livestock keeping, rope making, boat making, handcraft and small business (Walley, 2004; Mwaipopo, 2008).

Chole and Jibondo villages are among the inhabited islands of the archipelago that were chosen for this study. According to village records of 2011, Chole had about 243 households while Jibondo had 620. They were selected because each constitutes a small fishing village with inhabitants that heavily depend on fish as a major source of protein but where they are also affected with global processes in different ways. Conservation measures by the MIMP for example, are reported to affect both Chole and Jibondo villagers (Benjaminsen \& Bryceson, 2012). Chole was also selected because of the presence of tourism foreign investment and for its reported high level of poverty and substantial decrease of fish intake (Walley, 2004; Bryceson et al., 2006). Jibondo was selected because of its active engagement in small-scale commercial fishing and trade through agents from the fish processing factory and the reported changes in gender roles that compromise food security (Bryceson et al., 2006). 


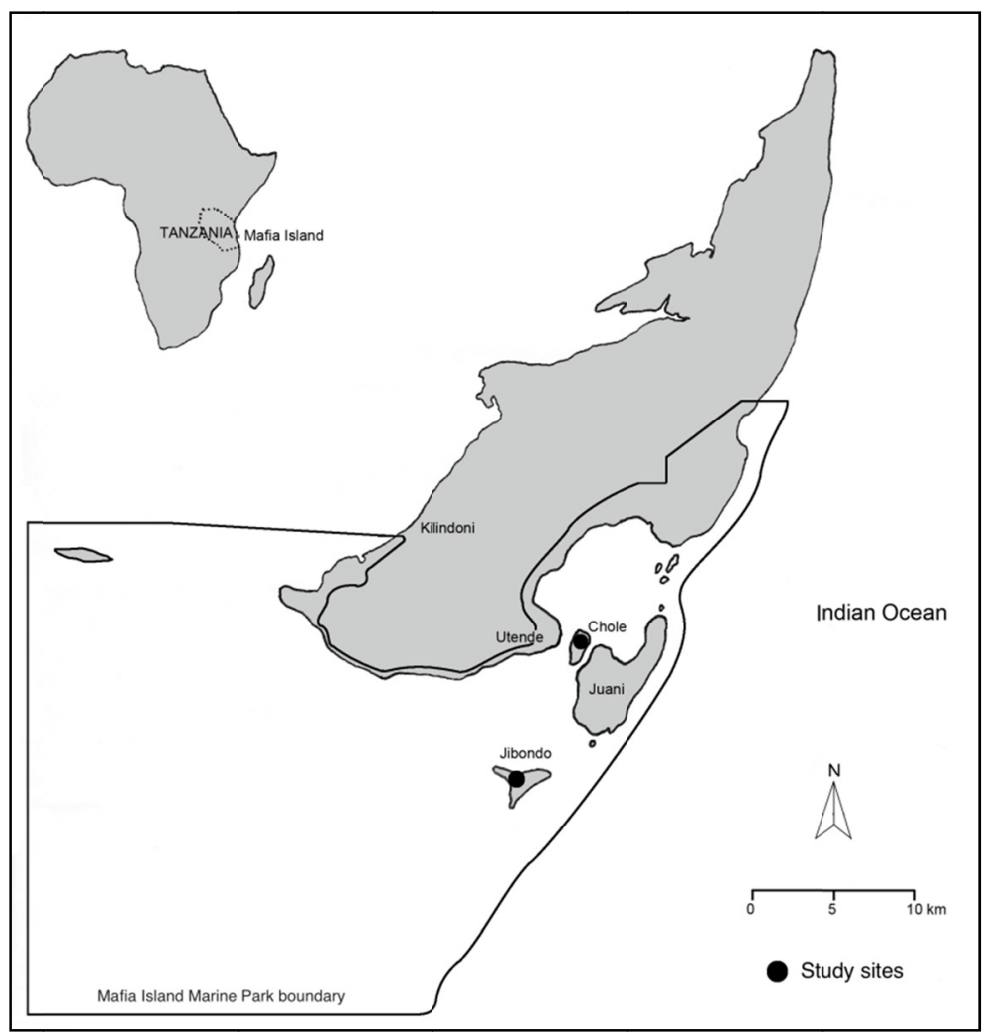

Figure 1. Map of Mafia Island showing study sites

\subsection{Data Collection}

This was a descriptive cross-sectional study conducted for eight months between August 2009 and March 2011 using both quantitative and qualitative data collection methods. It was part of a much wider social-ecological study that was carried out in the two sites to investigate social-ecological changes in the livelihoods of people residing in the sites. Data collected in the wider study included changes in income and food status in terms of number of meals per day, types and amounts of foods consumed, trends in the consumption of fish and other alternative protein-rich foods. Data collection for this study was carried out after being granted research clearance by the University of Dar es Salaam and permission to collect data by the responsible government authorities at regional, district and village levels. Verbal informed consent was obtained from the mothers and guardians of under-five children through the help of village leaders and officials from the kindergarten and dispensaries.

Target population for the study was under-five children residing in Chole and Jibondo villages. This study involved children who were enrolled in Chole Kindergarten and those brought to Reproductive and Child Health $(\mathrm{RCH})$ clinics in Chole and Jibondo villages. Reasons being first, the timing of data collection coincided with school operations such that the under-fives aged above two and a half years from Chole were found at the kindergarten. Second, in Tanzania, all children under the age of five are supposed to attend the RCH clinic once in every month for growth and development monitoring including vaccination. Therefore, quantitative data collection involved under-five children that attended RCH clinic in the month of February 2011 in order to quantify the rate of attendance of under-fives to the $\mathrm{RCH}$ clinic for one month. This included the rest of the under-fives from Chole that were not enrolled at the kindergarten but were brought to the clinic during the stated period.

The total number of the under-five children was obtained from Chole and Jibondo dispensaries in the RCH record books. The RCH records showed there were 252 under-five children in Jibondo Island and 77 in Chole Island. A total of 104 and 52 children from Jibondo and Chole respectively were involved in this study. In Jibondo, RCH services for the under-fives were scheduled to take place once every week on Wednesdays whilst in Chole the services were available every working day. Therefore data collection at Jibondo was done only on Wednesdays and other weekdays at Chole while the Wednesdays' data for Chole were obtained from the RCH record book. The health care worker on duty for the day and the first author performed anthropometric 
measurements and recorded data on prepared forms. Weight was taken after the participants had removed their shoes and upper garments and was measured to the nearest $0.1 \mathrm{~kg}$ using SALTER and ADE weighing scales, which were periodically checked for accuracy and calibrated as necessary. Children's chronologic age was calculated as a decimal age by subtracting the measurement date from the date of birth. At Chole, measurements of the under-five children enrolled at Chole Kindergarten were taken at the dispensary and their birth date records were obtained from $\mathrm{RCH}$ records and the rest of under-five data was recorded during clinic services. At Jibondo, data on weight were recorded during clinic services and data on birth date and weight were recorded from child's clinic cards.

Qualitative data collection focused on exploring local perceptions of possible explanations with regard to nutritional status of the under-fives. Data on the topics pertaining to children's upbringing, such as the duration before mothers resumed their income generating activities, particularly seaweed farming and octopus picking, changes in gender roles, breast feeding, introduction of substitute foods, child diet and major causes of morbidity were collected through in-depth interviews and Focus Group Discussions (FGDs). In Chole, ten interviews were held with women, men, kindergarten teacher and healthcare official while four FGDs were conducted, two with women, one with both men and women and the last with kindergarten cooks. In Jibondo, fourteen interviews with women, care givers, men and healthcare official for the village dispensary were held. Five FGDs were conducted, four with women and one with both men and women. Personal observations and informal talks were also useful to complement data obtained from interviews and FGDs.

\subsection{Data Analysis}

Quantitative data from completed forms were checked for consistency before data entry was conducted. Descriptive analysis was done and the results were presented as proportions. Child's weight for age was interpreted using World Health Organization (WHO) growth charts (2006). These growth charts were used because they are the basis for $\mathrm{RCH}$ card number one used in Tanzania for monitoring growth and development in children below the age of five years. Weight for age values falling at the median was taken as normal nutritional status and at -1 standard deviation (-1SD) as mild low weight for age. If the child's weight for age lies between -2 and -3 Standard deviation was reported as moderate low and if below -3SD was taken as severe underweight or very low weight for age. Qualitative data from interviews and FGDs were transcribed and the field notes were organised and reviewed repeatedly to identify emerging themes which were then categorised into major themes for description (Bryman, 2004).

\section{Results}

Of the 156 children below the age of five years involved in this study, 104 (67\%) were from Jibondo Island and $52(33 \%)$ were from Chole Island, representing $41 \%$ and $68 \%$ of the total under-five children at Jibondo and Chole respectively. Among them males were 81 (52\%) and infants (children aged less than 12 months) were 43 (28\%) of the studied population. Of the total 252 under-five children at Jibondo, 148 (59\%) children did not attend their monthly RCH clinic.

About $40 \%$ of the studied population did not suffer from underweight. Most of these children with normal weight for age were infants, accounting for $74 \%$ of the studied infants. The rest $(60 \%)$ of the studied population were underweight. Among the underweight children, $35 \%$ had mild, $43 \%$ moderate and $22 \%$ severe low weight for age. The majority of those with mild to severe low weight for age were those above one year of age (Figure 2). 


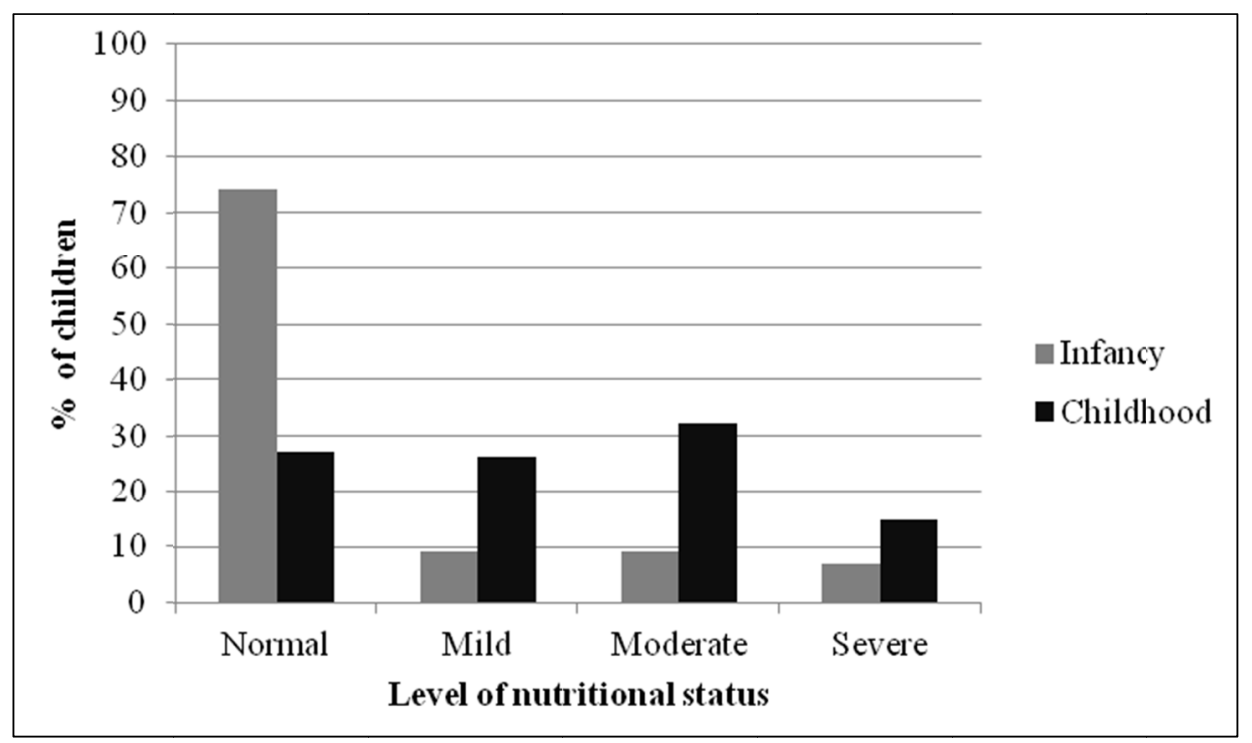

Figure 2. Level of nutritional status (underweight) by age

Infancy $=$ child aged less than 12 months, Childhood= child aged 12 months to 59 months.

The prevalence of underweight children in the two sites differed (see Figure 3). In Chole $40 \%$ of the studied children were underweight. In Jibondo the levels of underweight children among the sample were higher (69\%). Of the studied children in Jibondo, 20\% had mild and 30\% had moderate while 19\% had severe underweight. In Chole, $17 \%$ of the children involved in the study had moderate underweight. All of the severe underweight children of the total studied population were from Jibondo. However, only $8 \%$ of the sampled children in Jibondo had low birth weight that was below $2.5 \mathrm{~kg}$.

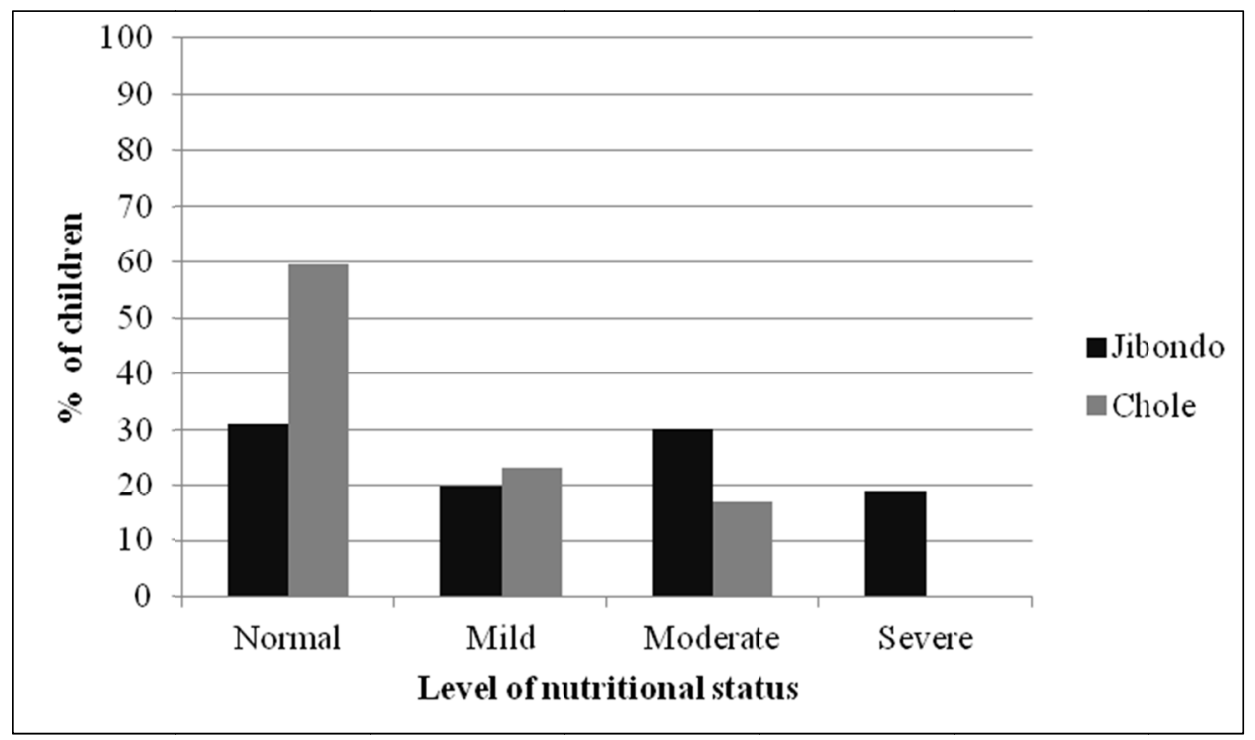

Figure 3. Level of nutritional status (underweight) by area of residency

Qualitative results revealed that most mothers in Chole still breast fed their children as in the past because their important activities for generating income and food production, rope making, handcrafts and farming, took place around their homesteads. Few mothers farmed at the neighbouring island, Juani, during the April-June and November-January farming seasons. They reported that they experienced increased responsibilities for household needs because men faced reduced fish catches and income from fishing restrictions, consequently reducing household nutritious food and fish supply. A 36 year-old man, a father of four children, noted that “... 
when I am stuck, I leave in the morning without saying goodbye to my wife, and she attends to the household needs then she claims the money". (IDI with a man, Chole village, 02/03/2011). However, household expenses were greatly reduced because parents did not cover higher education costs for their children as sponsorships to all children who passed their primary school examinations were provided through an initiative that was introduced by the tourism investors. Women pointed out that most households' struggles were for obtaining food and other needs, and that their children were not affected much by the increased work-load because Chole women were not such hard workers as those in the neighbouring islands as explained by one woman:

“... We people of Chole are not that active, we are just like that ... maybe because this island was colonized by Arabs. They made as like 'stay inside only'- a woman is not a person that is supposed to struggle, a woman is a person for keeping inside..." (IDI with a woman, Chole Village, 12/10/2010).

Most of the Chole children were cared for at the kindergarten during working days and were provided with nutritious food. In the mornings, children were fed porridge that was made from nutritional flour, which was a mixture of sorghum, bulrush millet, finger millet, maize and soya beans. For lunch, stiff porridge, rice, bananas, potatoes and pasta were interchangeably served with either beans or small sized fish except on Fridays when either chicken or beef was served. Women who cooked for the 58 children enrolled at the kindergarten at the time of data collection admitted that the quality and varieties of foods provided at the kindergarten contributed much to the nutritional status of their children because such varieties were not available in households. However, they also reported to have reduced portions of both breakfast and lunch due to decreased ability to operate the school.

In Jibondo, the frequency and duration of breast-feeding among the under-fives had reduced substantially because mothers resumed seaweed farming and octopus fishing soon after delivery. Seaweed farming and octopus fishing are important livelihood activities to the majority of women for both household income and food security in the area and are practiced during the two spring tide periods in each month, about sixteen days a month. During these days women usually left at around 7-9 am and returned in the afternoons around $2 \mathrm{pm}$ depending on tides. Mothers resumed breast-feeding when they returned from the ocean. Most mothers resumed their livelihood activities soon after 40 days as evidenced by one woman:

“....women resume going to the ocean soon after arobaini (a period of 40 days). It would not pass two months after the arobaini before women resume seaweed farming and octopus fishing. There is not enough income from net fishing by children's fathers such that home provisions drop. We just have to resume early because things don't go well when women stay grounded for long. Even husbands will not approve of women being grounded for say six months even when the doctor advises them to do so ..." (FGD with women, Jibondo village, 13/01/2011).

Cases were reported of mothers resuming seaweed farming and octopus fishing in less than a month after delivery. An extreme case was reported of one mother who resumed her fishing activities within a week after she had delivered, and the child was found to be underweight. However, there were still some mothers who waited up to eight months before they resumed their activities.

The tendency of mothers to resume livelihood activities soon after delivery was further evidenced by the existence of child caring activities among the elderly women at Jibondo. One elderly woman (above 70 years of age) confirmed that most women resume octopus fishing and seaweed farming after arobaini such that she was earning part of her livelihood by taking care of children whose mothers had resumed working in the ocean early after delivery. She fed the children with plain porridge and in few cases milk that was provided by mothers before they left for work. She explained that she cared for about six children every spring tide.

Mothers attributed their early return to income-generating activities to changes in gender roles and increased responsibilities for women in Jibondo. They experienced these changes since the 1980s and stated that they have increased in the preceding two decades. In the past, during spring tides, men engaged in fishing while women practiced octopus fishing and they both engaged in farming on land during neap tides and raining seasons to produce various crops for household consumption such that they did not purchase food. Since 1990s crop production was left to women and started to decline due to destruction by livestock, while men focused on fishing. Women were concerned that these changes and the decrease of governmental assistance in providing health and education services have increased household expenses to the extent that was not manageable by men alone. However, examples were reported that when women earned income to run the households, some men began to provide less for their families and entered into polygamy. These changes in gender roles and responsibilities in Jibondo are reflected in the following quotes from three women: 
“... When I was married in 1971, I waited for my husband to provide for both household and my needs. My major responsibilities were to clean the house, wash clothes, cook, reproduce and care for the children. I did not think of business and even when my husband left money for household expenses I returned the surplus to him. Now I cover educational expenses for my children in both secondary and primary school, I used the income I got from my last seaweed harvest to buy cement and built this cement floor that we are sitting on now, I bought 10 goats and my husband has one. Men's income has dropped because of frequent confiscation of their fishing gear and they have now shifted to octopus diving. In the past octopus was women's work only and seaweed had no meaning ..." (IDI with a woman, Jibondo village, 02/10/2010)

“... Now most women build houses and feed their families either alone or in co-operation with their husbands. Men have now experienced ease of life because life has knocked them down. They don't provide household provisions in time and they dodge household expenses so that women would provide ..." (IDI with a woman, Jibondo village, 15/09/2010).

“... In the past women did not hide their money but now they hide it so that the husband don't see it, because when he sees it he takes it and go to propose marriage to another woman ..." (FGD with women, Jibondo Village, 28/09/2010).

Men admitted to have lost their capacity to fully provide for both their wives' and households' needs as they did in the past, and acknowledged the increased workload to women. Most men appreciated women's support in running the households while some men were not guaranteed support and to others it meant new opportunity to enter polygamy and bare children despite their economic hardships and reduced abilities to care for them. Cases of reduced family care among young fathers were also reported whereby they prioritize their spending on clothing to catch-up to their peers in Kilindoni and the current trends that are seen in televisions at video halls. These phenomena are captured in the following quotes from men.

“... Now we just manage life partly, life is like so. The situation is tough, if we (himself and his wife) don't help each other, things don't work out ..." (IDI with a man, Jibondo village, 02/10/2010).

“... Now my income is low although octopus prices are a bit higher. In the past the income was high although the prices were low. Woman's income is not guaranteed, she hides it because she is married ..." (IDI with a man, Jibondo, 01/10/2010).

“... You can just marry even three wives. Women here feed themselves. But in case of divorce, a man is the one who leaves the house because most houses are mainly built by women ..." (IDI with a man, Jibondo village, 27/09/2010).

“... We are not smart like the elders, you buy a 30,000 TSh [approximately 20 USD] jeans while you have no savings. We are finishing perfumes in shops while the elderly used coconut oil. The youth don't mend nets, they pay 5,000 TSh [approximately 3.5 USD] per gear to elders or those who want to learn. At what time will they be seen in Kilindoni if they mend nets?" (IDI with a young man, Jibondo, village, 01/10/2010).

The reported increase in earning responsibilities among women contributed to decreased ability for mothers to follow the advice from the clinical officer who urged them to wait to resume their activities until six months after delivery in order to exclusively breastfeed. During this study, it was generally agreed by both women and the clinical officer that there was not a single woman at Jibondo who exclusively breastfed her child for the first six consecutive months. The clinical officer reported requesting mothers to come with the fathers of their babies during their monthly visits to the RCH clinic. This would be an opportunity for the clinical officer to advise both parents on the importance of delaying resumption of income earning activities among mothers so as to breastfeed infants exclusively during the first six months of their babies' lives. However such plans did not materialize because fathers were reported to fear that they would be tested for HIV infection.

The altered breastfeeding practices at Jibondo entailed early introduction of substitute food among infants during their early stages of life. Most substitute foods were mainly nutrient poor and carbohydrate rich, like maize flour served as a watery porridge. Meanwhile, the rate of supplementing fresh cow's milk to infants was reported to remain low due to both limited availability and affordability. Children above one year were less breastfed, and were fed on low nutritional substitute foods and family meals containing more carbohydrates and little or no foods that are rich in protein, vitamins and minerals.

Incidences of diarrhea among infants were reported by women and confirmed by the clinical officer, particularly at Jibondo. The officer reported early introduction of substitute foods before the babies' digestion systems were 
ready and poor hygiene as major causes of most diarrhea cases, which further exacerbated cases of underweight in the area. Other causes of morbidity among the under-fives were reported to include malaria, respiratory infections and iron deficiency anaemia, which also affected most women. During their visits to the clinic, mothers were advised to include green vegetables in meals. However, it was reported that households could not afford the vegetables on daily basis.

\section{Discussion}

Most of the changes experienced by villagers in Chole and Jibondo, including fishing restrictions, reduced income and altered gender roles appear to have negatively affected the nutritional status of the under-five children. As our results show, almost $60 \%$ of the studied children below five years were underweight. This is despite the fact that MIMP has a specified obligation to ensure that the wellbeing of the communities residing within the borders of the park is maintained by broadening their income base through new livelihood activities (URT, 2000). The observed percentages of the underweight in this study were almost four times higher than the national standards reported in the 2010 Tanzania Demographic and Health Survey (URT, 2011), which revealed that $16 \%$ of Tanzanian under-five children studied during the survey were underweight, with Arusha region having the highest rates (28\%). Nyaruhucha et al. (2006) and Abubakar, Uriyo, Msuya, Swai, and Stray-Pedersen (2012) observed high underweight rates in northern Tanzania, in Manyara (31\%) and Kilimanjaro (19\%) respectively. The percentage of severely underweight children in our study (13\%) was more than three times than the national rates (4\%) (URT, 2011). This is probably due to low income from fish trade and increased protectionist measures by MIMP (Bryceson et al., 2006; Benjaminsen \& Bryceson, 2012).

The degree of underweight in study areas varied across age groups, with children below one year of age being the least affected with underweight problems. This could be partly due to the fact that infants were breastfed. It was observed in this study that women resumed their livelihoods activities soon after delivery but they ensured substitute foods for their infants and continued with breastfeeding when they returned home, and maternal care was probably good for this age group. On the other hand, children above one year were less breastfed, and were fed on low nutritional meals. Early introduction of low quality substitute foods along with poor hygiene has been argued to exacerbate undernutrition problem and increased incidences of diarrhea among under-five children (de Onis, Frongilo, \& Blössner, 2000; Bloss, Wainana, \& Bailey, 2004; Kumar, Goel, Mitta, \& Misra, 2006; Muhimbula \& Isa-Zacharia, 2010). About $26 \%$ of infants in this study were underweight probably because women did not practice exclusive breast feeding for six months as recommended by WHO (2002) and UNICEF (2011).

Reduced care among the under-fives was also evidenced in Jibondo where more than half of the under-five children in the study site not brought to their monthly clinic. Falls in attendance to clinic by the children above one year were also reported in the study by Matee et al. (1997). Most studies on nutritional status of under-fives have indicated the vulnerable age for undernutrition to be mostly children above six months, a period during which intensification of nutritionally insufficient substitute foods were reported (UNICEF, 1998; Muhimbula \& Isa-Zacharia, 2010; URT, 2011; Walton \& Allen, 2011).

Jibondo was more affected with undernutrition, although only a few of the sampled children had lower birth weight than the $2.5 \mathrm{~kg}$ recommended as normal birth weight by Blössner and de Onis (2005) and URT (2011). This was probably because the nature and dominance of women activities and their household responsibilities in the two sites differed and the women in Jibondo were more engaged in work and were responsible for covering education costs for their elder children. Women in Chole were thus more likely to have more time for child caring than their counterparts in Jibondo. Spatial differences in malnutrition have also been observed by Kandala, Madungu, Emina, Nzita and Cappuccio (2011) and Jesmin, Yamamoto, Malik, \& Haque (2011).

Another possible explanation for this variance might be the difference in food security status experienced in the two sites. Chole villagers produced most of their foods but lacked fish protein as also observed by Walley (2004), while in Jibondo poor soils and declining agriculture has increased food insecurity and dependence on purchased food. The increased protectionism by the MIMP and lower prices for fish, octopus and seaweeds (Bryceson et al., 2006; Benjaminsen \& Bryceson, 2012) largely reduced income and constrained purchasing power for food. Studies by Alderman, Hoogeveen and Rossi (2006), Evans et al. (2011) and Kandala et al. (2011) have also shown the influence of income on dietary patterns where the amount of income determined the amount that was to be spent on food purchase.

Feeding programs among children have been argued to have potentials for reducing undernutrition cases (Levinger, 1986). The presence of a kindergarten school at Chole is yet another possible explanation of the lower rate of underweight children in the area than those at Jibondo. The presence of the kindergarten also meant that 
children at Chole were likely to have more meals per day than children from Jibondo who were mainly left with elderly women when their mothers went to work.

It has been shown in this study that the prevalence of low underweight in both sites has been largely contributed to by the increased burden on women, whereby they spent much time on livelihood activities either to raise income for purchasing food or to produce food directly. The problem of balancing time for child rearing activities and livelihood activities has also been reported in Southern parts of the country in Rukwa Region by Wandel and Holmboe-Ottesen (1992) and in the neighboring country in Kenya by Abubakar, Holding, Mwangome and Maitland (2011). However, Mahgoub et al. (2006) observed significant decrease of underweight cases among the under-fives with increase of household income. This suggests that child malnutrition could have been even worse than what was observed during this study if the mothers had taken more time before they resumed their livelihood activities after delivery. This is because villagers in both sites have been reported to face increased economic hardships (Walley, 2004; Benjaminsen \& Bryceson, 2012) and men were already having difficulties in providing household needs without such assistance from their spouses. Women had possibly made hard decisions when they had to resume their activities soon after delivery in order to ensure food requirements for their other elder children and the whole household. By making this choice, women were ultimately struggling to maintain their traditional role - taking care of their children and the entire family whilst also ensuring that food requirements are met (Seebens, 2010).

The argument by Oppong (2001) and Gabriele and Schettino (2008) that past and present macro political and economic trends of global systems contribute to undernutrition problem among children was also evident in this study. The introduction of Structural Adjustment Programmes in Tanzania as a conditionality for foreign aid and loans during the 1980s is widely argued to have affected the poor adversely by causing devaluation of local currency, introducing cost sharing in health and education, increased prices and promoting trade liberalisation (Lugalla, 1995; Walley, 2004; Caplan, 2007). The effects of liberalisation of fish trade on food security and undernutrition by moving fish from where it is most needed due to unaffordability of other protein-rich foods to areas where it less needed at lower prices is also widely documented by Kent $(1985,1997,2002)$, Fulgencio (2009) and Allison (2011). These global processes in combination with other local factors, including changes in gender roles, decreased income and devaluation of money appear to have contributed to the underweight problem in this study.

However, in order to understand such contributory explanations with regard to nutritional status of under-fives in the two sites, one must take into consideration major limitations of this study. First, the selection of under-five children into the study by mainly depending on their attendance to the dispensaries implied handling a number of children within the allocated time for RCH clinics. This limited the amount of time spent with individual child and mother; consequently hampered the collection of quantitative data regarding causes of undernutrition from the mothers of the sampled children. Although this limitation was partly addressed by the qualitative explanations provided in this study, it remains unfeasible to generalize such explanations as exact factors that contributed to undernutrition problem among all the under-fives in the two sites. Second, our focus on understanding attendance of under-five children to $\mathrm{RCH}$ clinics eliminated more than half of eligible children from participating in this study since they were not brought to the clinics. Even though this study described the nutritional status of the involved children through the small sample size obtained, it is important for future studies to sample participants at household level to avail more time for collecting other quantitative data and obtain larger sample size.

\section{Conclusions}

In line with the limitations mentioned above, several conclusions are made. Most of the under-five children who were involved in this study were underweight, reflecting the failure to meet their nutritional requirements. The problem of underweight was higher in Jibondo than in Chole. The difference that was observed between the two villages in the same district, especially in comparison to national rates, highlights the importance of contextual conditions and demonstrates that the use of national averages may actually obscure the worst scenarios of child undernutrition. The study has also revealed how the situation in Chole and Jibondo is not meeting the stated goals of MIMP's General Management Plan to ensure the wellbeing of the communities within the park, and the United Nations MDGs targets related to child health.

The local perceptions of prevalence of underweight in these cases suggest that underweight was mainly attributed to changes that were happening in the Mafia Island Marine Park. These changes included decreased income among men, increased food insecurity and increased responsibilities and burden among women to contribute to household needs. The important distinctions between women's roles in the two sites had 
implications for child-care while the kindergarten meals played important role in improving nutritional status among children in Chole. There is a need for an in-depth multidisciplinary study that includes other anthropometric measures and in-depth epidemiological assessments among the under-fives at Jibondo, Chole and other parts of Mafia. If healthy generations and sustainable social-ecological systems are to be achieved within the Park in the future, interventions that review fishing restrictions, improve fish trading, increase household food security and liberate mother's time for breastfeeding and child-caring activities would be essential to address the current undernutrition among the under-fives.

\section{Acknowledgements}

We express our gratitude to mothers and children in Chole and Jibondo villages for their active participation and co-operation in this study. We thank the officials in the village dispensaries and Chole Kindergarten for their tireless support throughout the study. We would like to thank Rose Mwaipopo, Siri Damman and the anonymous reviewers for providing insightful comments and suggestions. The funding of this study was provided by the Norwegian Centre for International Cooperation in Higher Education (SIU) under Norwegian Programme for Development, Research and Education (NUFU).

\section{References}

Abubakar, A., Holding, P., Mwangome, M., \& Maitland, K. (2011). Maternal perceptions of factors contributing to severe under-nutrition among children in a rural African setting. Rural and Remote Health, 11, 1423. Retrieved from http://www.rrh.org.au

Abubakar, A., Uriyo, J., Msuya, S. E., Swai, M., \& Stray-Pedersen, B. (2012). Prevalence and risk factors for poor nutritional status among children in the Kilimanjaro Region of Tanzania. International Journal of Environmental Research and Public Health, 9, 3506-3518. http://dx.doi.org/10.3390/ijerph9103506

Albonico, M., Ramsan, M., Wright, V., Jape, K., Taylor, M., Savioli, L., \& Bickle, Q. (2002). Soil transmitted nematode infections and mebendazole treatment in Mafia Island schoolchildren. Annals of Trop. Med. Parasitology, 96, 717-726. http://dx.doi.org/10.1179/000349802125001942

Alderman, H., Hoogeveen, H., \& Rossi, M. (2006). Reducing child malnutrition in Tanzania: combined effects of income growth and program interventions. Economics and human Biology, 4, 1-23. http://dx.doi.org/10.1016/j.ehb.2005.07.001

Allison, E. H. (2011). Aquaculture, fisheries, poverty and food security. Working Paper. 2011, 65. Malaysia. World Fish Center.

Andrews, G. (1998). Mafia Island Marine Park, Tanzania: Implications for applying a Marine Park Paradigm in a developing country. Retrieved from www.oceandocs.net/handle/1834/905

Ash, D., Takala, S., \& Latham, M. C. (2007). Community driven comprehensive anemia control program can reduce anemia and improve overall health and nutritional status. Abstract in Micronutrient Forum Istanbul, Turkey.

Retrieved

from http//www.micronutrientforum.org/Meeting2007/MN\%20Forum\%20Program\%20Part\%20II_Abstracts.pdf

Benjaminsen, T. A., \& Bryceson, I. (2012). Conservation, green/blue grabbing and accumulation by dispossession in Tanzania. Journal of Peasant Studies, 39(2), 335-355. http://dx.doi.org/10.1080/03066150.2012.667405

Berkes, F., \& Folke, C. (Eds). (1998). Linking social and ecological systems: Management practices and social mechanisms for building resilience. Cambridge University Press.

Black, R. E., Allen, L. H., Bhutta, Z. A., Caulfield, L. E., de Onis, M., Ezzati, M., ... Rivera, J. (2008). Maternal and child undernutrition: global and regional exposures and health consequences. Lancet, 371, 243-260. http://dx.doi.org/10.1016/S0140-6736(07)61690-0

Bloss, E., Wainana, F., \& Bailey, R. C. (2004). Prevalence and predictors of underweight, stunting and wasting among children aged 5 and under in Western Kenya. Journal of Tropical Pediatrics, 50(5), 260-270. http://dx.doi.org/10.1093/tropej/50.5.260

Blössner, M., \& de Onis, M. (2005). Malnutrition: Quantifying the health impact at national and local levels. Environmental Burden of Desease Series. No 12. Geneva. WHO.

Bryceson, I., Jiddawi, N., Kamukuru, A., Kulindwa, K., Mwaipopo, R., Onyango, P., \& Sebastian, M. (2006). Fisheries study in Tanzania coastal waters: the effects of trial export of finfish from Mafia Island on social-ecological resilience and vulnerability. 
Bryman, A. (2004). Social research methods (2nd eds.). Oxford: Oxford University Press.

Caplan, P. (2007). Between socialism \& neoliberalism: Mafia Island, Tanzania, 1965-2004. Review of African Political Economy, 114, 679-694. http://dx.doi.org1080/03056240701819541

De Onis, M., Blössner, M., Borghi, E., Frongilo, E. A., \& Morris, R. (2004). Estimates of global prevalence of child underweight in 1990 and 2015. American Medical Association, 291, 21.

De Onis, M., Monteiro, C., Akre, J., \& Glugston, G. (1993). The worldwide magnitude of protein-energy malnutrition: an overview from the WHO Global Database on Child Growth. Bulletin of World Health Organization, 71(6), 703-712.

De Onis, M., Frongilo, E. A., \& Blössner, M. (2000). Is malnutrition declining? An analysis of changes in levels of child malnutrition since 1980. Bull World Health Organization, 78.10. Genebra

Evans, A., Seth, J. G., Smith, S., Harris, K. K., Loyo, J., Spaulding, C., ... Gottlieb, N. (2009). Potential feeding practices and concerns related to child underweight, picky eating and using food to calm differ according to ethnicity/race, acculturation \& income. 2011. Matern Child Health, 15, 899-909. http://dx.doi.org/101007/s10995-009-0526-6

Fulgencio, K. (2009). Globalisation of the Nile perch: Assessing the sociocultural implications of the Lake Victoria fishery in Uganda. African Journal of Political Science and International Relations, 3(10), 433-442. Retrieved from http://www.academicjournals.org/ajpsir

Gabriele, A., \& Schettino, A. (2008). Child malnutrition and mortality in developing countries: Evidence from cross-country analysis. Analysis of Social Issues and Public Policy, 8(1), 53-81. http://dx.doi.org/10.1111/j.1530-2415.2008.00157.x

Garpe, K. C., \& Öhman, M. C. (2003). Coral and fish distribution patterns in Mafia Island Marine Park, Tanzania: fish-habitat interactions. Hydrobiologia, 498, 191-211. http://dx.doi.org/10.1023/A:1026217201408

Jesmin, A., Yamamoto, S. S., Malik, A. A., \& Haque, A. (2011). Prevalence and determinants of chronic malnutrition among preschoolchildren: a cross-sectional study in Dhaka City, Bangladesh. J. Health Popul Nutr., 29(5), 494-499

Kandala, N. B., Madungu, T. P., Emina, J. B. O., Nzita, K. P. D., \& Cappuccio, F. P. (2011). Malnutrition among children under the age of five in the Democratic Republic of Congo (DRC): does geographical location matter? BMC Public Health, 11, 261. http://dx.doi.org/10.1186/1471-2458-11-261

Kent, G. (1985). Fisheries and undernutrition. Ecology of Food and Nutrition, 16, 281-294. http://dx.doi.org/10.1080/03670244.1985.9990867

Kent, G. (1997). Fisheries, food security and the poor. Food Policy, 22(5), 393-404. http://dx.doi.org/10.1016/S0306-9192(97)00030-4

Kent, G. (2002). Africa's food security under globalization. African Journal of Food and Nutritional Sciences, 2, 1.

Kumar, D., Goel, N. K., Mitta, P. C., \& Misra, P. (2006). Influence of infant-feeding practices on nutritional status of under-five children. Indian Journal of Pediatrics, 73(5), 417-421. http://dx.doi.org/10.1007/BF02758565

Leach, V., \& Kilama, B. (2009). Preventing malnutrition in Tanzania: A focused strategy to imrove nutrition in young children. REPOA Brief. Dar es Salaam. Research on Poverty Alleviation.

Levinger, B. (1986). School feeding programs in developing countries: An analysis of actual and potential impact. Washington DC. USAID Evaluation Special Study Report 30. Retrieved from http://www.schoolsandhealth.org/sites/ffe/Needs\%20Assessment/pnaal060.pdf

Lugalla, J. L. P. (1995). The impact of Atructural adjustment Policies on women's and children's health in $\begin{array}{llllll}\text { Tanzania. } & \text { Review of African Political Economy, 22(63), 43-53. }\end{array}$ http://dx.doi.org/10.1080/03056249508704099

Mahgoub, S. E. O., Nnyepi, M., \& Bandeke, T. (2006). Factors affecting prevalence of malnutrition among children under three years of age in Botswana. Af. J. Food Agr. Nutr. Dev, 6, 1-15.

Matee, M. I., Msengi, A. E., Simon, E., Lyamuya, E. F., Mwinula, J. H., Mbena, E. C., ... Scheutz, F. (1997). Nutritional status of under fives attending maternal and child health clinics in Dar es Salaam, Tanzania. East 
Afr. Med. Journal, 74(6), 368-371.

McGregor, S. G., Cheung, Y. B., Cueto, S., Glewwe, P., Richter, L., Strupp, B., \& the International Child Development Steering Group. (2007). Child development in developing countries: Developmental potential in the first 5years of children in developing countries. Series, 1369. Retrieved from www.thelancet.com

Moshy, V., Bryceson, I., \& Beymer-Farris, B. (2012). Seeing through fishers' lenses: Exploring marine ecological changes within Mafia Island, Tanzania. Proceedings of the International Conference on Fisheries and Marine Science (Marine Fish 2012), Negombo, Sri Lanka.

Muhimbula, H. S., \& Issa-Zacharia, A. (2010). Persistent child malnutrition in Tanzania: Risks associated with traditional complementary foods. African Journal of Food Science, 4(11), 679-692.

Muller, O., \& Krawinkel, M. (2005). Malnutrition and health in developing countries. Can. Med. Assoc. J., 173, 279-293. http://dx.doi.org/10.1503/cmaj.050342

Mwaipopo, R. N. (2008). The Social Dimensions of Marine Protected areas: A Case Study of Mafia Island Marine Park Tanzania. India: International Collective in Support of Fishworkers.

Nubé, M., \& Sonneveld, B. G. J. S. (2005). The geographical distribution of underweight children in Africa. Bull World Health Organ, 83, 10.

Nyaruhucha, C. N. M., Msuya, J. M., Mamiro, P. S., \& Kerengi, A. J. (2006). Nutritional status and feeding practices of under-five children in Simanjiro District, Tanzania. Tanzania Health Research Bulletin, 8(3), $162-167$.

Öhman, M. C., Lindahl, U., \& Schelten, C. K. (1999). Influence of coral bleaching on the fauna of Tutia Reef Tanzania. Status reports from different regions, 7(10). Retrieved from www.oceandocs.net/handle/1834/491

Oppong, C. (2001). Globalization and the disruption of mother care. Research Review, 17(1), 25-47.

Pelletier, D. L., Frongillo, E. A., Schroeder, D. G., \& Habicht, J. P. (1995). The effects of malnutrition on child mortality in development countries. Bull World Health Organ, 73(4), 443-448.

Seebens, H. (2010). Intra-household bargaining, gender roles in agriculture and how to promote welfare enhancing changes. ESA Working Paper No. 11-10. Agriculture development economics division. Food and Agriculture Organization of the United Nations. Retrieved from www.fao.org/economic/esa

Shetty, P. (2003). Malnutrion and undernutrition. Medicine, 31, 18-22. http://dx.doi.org/10.1383/medc.31.4.18.27958

Smith, L. C., \& Had dad, L. (2000). Explaining child malnutrition in developing countries: A cross-country analysis. Washingtom. D.C. International Food Policy Research Institute.

Sunguya, B. F., Poudel, K. C., Otsuka, K., Yasuoka, J., Mlunde, L. B., Urassa, D. P., ... Jimba, M. (2011). Undernutrition among HIV -possitive children in Dar es Salaam, Tanzania: antiretroviral therapy alon is not enough. BMC Public Health, 11, 869. Retrieved from http://www.biomedcentra.com/1417-2458/11/869

United Nations. Millennium Development Goals. Retrieved from http://www.un.org/milleniumgoals

UNICEF. (1998). The state of world's children. Retrieved from www.unicef.org/sowc98/

UNICEF. (2009). Tracking progress on child and maternal nutrition. A survival and development priority. New York, USA.

UNICEF. (2011). Programming guide: infant and young child feeding. Nutrition section. Programmes. New York. Retrieved from www.unicef.org/videoaudio/PDFs/IYCF_programming_guide_May_26_2011.pdf

UNICEF. (2012). Humanitarian Action for Children. Retrieved from www.unicef.org/hac2012

URT. (2000). Mafia Island Marine Park. General Management Plan. Reserves, Dar es Salaam: Jamana Printers.

URT. (2007). Coast Region socio-economic profile. Second ed. Dar-es-Salaam: National Bureau of Statistics.

URT. (2011). Tanzania Demographic and Health Survey 2010. NBS and ICF Marco. Dar es Salaam, Tanzania.

URT. (2013). 2012 Population and housing census. Population distribution by administrative areas. Dar es Salaam and Zanzibar. National Bureau of Statistics and Ministry of Finance.

Walley, C. (2004). Rough Waters: Nature and Development in an East African Marine Park. New Jersey: Princeton University Press.

Walton, E., \& Allen, S. (2011). Malnutrition in developing countries. Paediatrics and Child Health, $21,9$. 
http://dx.doi.org/10.1016/j.paed.2011.04.004

Wandel, M. P., \& Holmboe-Ottesen, G. (1992). Food availability and nutrition in a seasonal perspective: A study from the Rukwa Region in Tanzania. Human Ecology, 20, 1. http://dx.doi.org/10.1007/BF00889697

WHO. (2002). Report of the expert consultation on the optimal duration of exclusive breast feeding. Geneva. Switzerland.

Retrieved

from www.who.int/nutrition/publications/infantfeeding/WHO_NHD_01.09/en/index.html

WHO. (2005). Severe malnutrition: report of consultation to review current literature 6-7 September 2004. Geneva, Switzerland.

WHO. (2006). WHO Child Growth Standards: length/height-for-age, weight-for-age, weight-for -length, weight-for-height and body mass index-for-age: methods and development. Multicentre Growth Reference Study Group. Geneva.

WHO. (2006). WHO Child Growth Standards based on length/height, weight and age. Multicentre Growth Reference Study Group. Acta Paediatr Suppl, 450, 76-85.

Young, O. R., Berkhout, F., Gallopin, G. C., Janssen, M. A., Ostrom, E., \& van der Leeuw, S. (2006). The globalization of socio-ecological systems: an agenda for scientific research. Global Environmental Change, 16(3), 304-316. http://dx.doi.org/10.1016/j.gloenvcha.2006.03.004

Zavoshy, R., Noroozi, M., Jahanihashemi, H., \& Kiamiri, D. (2012). Nutritional intervention on childhood malnutrition in rural nurseries in Qazvin Province, Iran. Zehedan Journal of Research in Medical Sciences, 14(5), 16-20. 